Annika Bärwald

\title{
7 Black Hamburg: People of Asian and African Descent Navigating a Late Eighteenth- and Early Nineteenth-Century Job Market
}

In 1821, an advertisement appeared in a Hamburg newspaper stating that "James Thomson, the Negro baptized here some years ago, born in Congo, twenty-six years of age," was "currently seeking a new position." The text asserted that Thomson had since "served in Harburg and Cöthen" - the former a town neighboring Hamburg, the latter the seat of a far-removed principality near Leipzig - and could "provide very laudable attestations from both masters." He was a capable man who knew "how to handle horses, and he dr[ove] reliably." Upon his return to Hamburg, Thomson had reconnected with people he had known for at least four years: Georg Bernhard Grautoff, the pastor of the local Church of St. Catherine who had baptized him in 1817 and now provided him with a recommendation, and Anna Margaretha Kasang, Thomson's godmother and an innkeeper with whom he stayed during his search for a job. ${ }^{2} \mathrm{Al}-$ though the advertisement consisted of only a few lines, it made clear that Thomson knew his way around and was acquainted with people he could rely on.

Thomson was not the only person of African descent in search of a paying occupation. Within five decades, from 1788 to 1839, at least twenty-one other people of non-European descent sought employment through Hamburg newspapers in similar

\footnotetext{
1 James Thomson, "Personen, welche ihre Dienste anbieten," Privilegirte Wöchentliche gemeinnützige Nachrichten von und für Hamburg, May 17, 1821, 117. In the following, advertisements will be referred to by newspaper acronym [WN for Wöchentliche Nachrichten, BH for Börsen-Halle, ACN for Addreß-Comtoir-Nachrichten], date, and page number only. All translations are my own.

2 See WN, May 17, 1821, 6; Hamburg State Archive, 512-4 St. Katharinen Kirche, A XVII a 19 II Taufbuch 1816-1818, 273.
}

\footnotetext{
Notes: I would like to thank my advisors and colleagues in Bremen as well as the attendants of the Global History Student Conference Istanbul 2018 and the History beyond Boundaries workshop organized by IEG Mainz in conjunction with Oxford University in 2019 for their helpful comments and suggestions on earlier versions of this text. Dan Durcan and Thom Lloyd provided invaluable help in copy editing the final version. All remaining mistakes are my own. This project is funded by the European Research Council (ERC) under the Horizon 2020 Research and Innovation Program of the European Union (Grant No. 641110 "The Holy Roman Empire of the German Nation and its Slaves"). However, this text exclusively reflects the author's views. The ERC is neither responsible for the content nor for its use.
} 
fashion. ${ }^{3}$ Although many more individuals of African and Asian descendance lived in the city than documented by these newspaper adverts, the texts are a specific window into employment practices and the self-presentation of non-white ${ }^{4}$ workers. As a source, despite representing only a small sample, they facilitate the assessment of occupational roles, strategies, and expectations assigned to laborers of non-European descent. Though most lack the level of detail volunteered by Thomson, the advertisements provide unique insights into the self-styling techniques and networks that non-white people used in late eighteenth- and early nineteenth-century northwestern Europe.

Employment strategies are rarely discussed by scholars studying people of Asian and African descent in early modern Europe, despite the centrality of work-related questions to numerous such research enquiries. Scholarship on Iberia and Britain, regions with comparatively high numbers of residents of African descent, suggests that service work and precarious positions were common. ${ }^{5}$ In many European countries, people of non-European origin were also employed in the maritime sector. ${ }^{6}$ These populations were far from homogenous, however: On one extreme end of the spectrum were individuals who achieved remarkable careers, on the other were significant numbers of non-white people who lived in legal or factual bondage throughout

3 Two of the twenty-three advertisements may refer to the same person; the number of twenty-two different individuals is thus a conservative estimate.

4 I explicitly wish to distance myself from biologistic understandings of the terms Black and white. Both white and Black were important - though not the only and not necessarily the dominant social categories used in eighteenth- and nineteenth-century Europe. Black, initially an ascription, has since been reappropriated and used as a term of self-identification by African-descended persons, including those of mixed descent, across the globe. By capitalizing the term, I follow this understanding. White, on the other hand, has historically often been understood as a rarely discussed standard connected to the absence of any (however constructed) non-white ancestry. I concur with demands to question the construction of whiteness but have nevertheless opted against the spellings white and White for reasons of legibility and to avoid confusion with right-wing uses of the term. Using "non-white" is owed to the circumstance that descent is often undeterminable. For general discussions on race and language, cf. Noah Sow, Deutschland Schwarz Weiß: Der alltägliche Rassismus, 6th ed. (Munich: Goldmann, 2009); Naomi Zack, Philosophy of Science and Race (New York: Routledge, 2002).

5 Cf. Peter Fryer, Staying Power: The History of Black People in Britain, new ed., (London: Pluto Press, 2010); Gretchen Gerzina, Black London: Life before Emancipation (New Brunswick, NJ: Rutgers University Press, 1995); A. C. de C. M. Saunders, A Social History of Black Slaves and Freedmen in Portugal, 1441-1555, Cambridge Iberian and Latin American Studies (Cambridge: University Press, 1982).

6 Cf. with regard to the Netherlands Mark Ponte, “'Al de swarten die hier ter stede comen': Een Afro-Atlantische gemeenschap in zeventiende-eeuws Amsterdam," TSEF/Low Countries Journal of Social and Economic History 15, no. 4 (2019): 33-62. See also Ray Costello, Black Salt: Seafarers of African Descent on British Ships (Liverpool: Liverpool Univ. Press, 2012); Michael Herbert Fisher, 
Europe. ${ }^{7}$ In this context, seeking employment via newspaper advertisements appears only in the margins of historiography. In her 2018 study, Danish historian Hanne Østhus mentions two such texts published in a Copenhagen newspaper in 1800 and 1803, each referencing a "Negro" seeking employment as a servant. ${ }^{8}$ Ineke Mok notes an Amsterdam newspaper advertisement from 1792 highlighting the language and hairdressing abilities of a man in Leiden. ${ }^{9}$ Michael H. Fisher cites the case of an Indianborn woman seeking employment in London in 1795, along with eight further advertisements by South Asians published between 1775 and $1798 .^{10}$ For all three authors, the advertisements are ancillary to the overall study of race and enslavement and are not themselves the subject of analysis.

German scholarship has likewise left the employment-seeking strategies of nonwhite people largely unexplored, with research typically focusing on persons living at noble courts and their representation and working conditions rather than on interactions with the urban wage labor market. ${ }^{11}$ Scholars have observed a tension inherent in these courtly positions characterized by relative privilege compared to rural servants on the one hand and ingrained dependency relationships on the other. There is an ongoing debate - sometimes held in starkly polarizing diction over whether the biographies of court employees should be understood primarily in terms of assimilation and integration or in terms of exclusion and exoticization. ${ }^{12} \mathrm{~A}$ different approach has recently been taken with the study of permutations of slavery

Counterflows to Colonialism: Indian Travellers and Settlers in Britain 1600-1857 (Delhi: Permanent Black, 2004).

7 Such exceptional biographies include philosophers, envoys, travelers, and princes; cf. e.g. Eric Martone, ed., Encyclopedia of Blacks in European History and Culture (Westport, CT: Greenwood Publishing Group, 2009). Recent scholarship has emphasized that bonded and impoverished persons were likewise active shapers of their own fate, cf. e.g. Sue Peabody, Madeleine's Children: Family, Freedom, Secrets, and Lies in France's Indian Ocean Colonies (New York, NY: Oxford University Press, 2017); Miranda Kaufmann, Black Tudors: The Untold Story (London: Oneworld, 2017).

8 Cf. Hanne Østhus, "Slaver og ikke-europeiske tjenestefolk i Danmark Norge på 1700- og begynnelsen av 1800-tallet,” Arbeiderhistorie 22, no. 01 (2018): 44-45.

9 Cf. Ineke Mok, "Slavernij in de Republiek 3: 'Zwarte negerjongen geabsenteerd,"” accessed February 15, 2018, https://www.cultuursporen.nl/2017/03/slavernij-in-de-republiek-3-zwarte-negerjongengeabsenteerd/.

10 Cf. Fisher, Counterflows to Colonialism, 230.

11 It has been noted that some court positions were filled by non-white people applying for these positions, cf. Karl-Heinz Steinbruch, "Ein schöner Mohr und treuer Diener: Auch an Mecklenburgs Höfen wurden Afrikaner getauft und in Dienst genommen," Mecklenburg-Magazin: Regionalbeilage der Schweriner Volkszeitung und der Norddeutschen Neuesten Nachrichten, no. 13 (2002): 22.

12 Cf. Peter Martin, Schwarze Teufel, edle Mohren, (Hamburg: Junius, 1993); Anne Kuhlmann-Smirnov, Schwarze Europäer im Alten Reich: Handel, Migration, Hof (Göttingen: Vandenhoeck \& Ruprecht, 2013); Monika Firla, Exotisch - höfisch - bürgerlich: Afrikaner in Württemberg vom 15. bis 19. Jahrhundert (Stuttgart: Hauptstaatsarchiv, 2001); Vera Lind, "Privileged Dependency on the Edge of the Atlantic World: Africans and Germans in the Eighteenth Century," in Interpreting Colonialism, ed. Byron R. Wells (Oxford: Voltaire Foundation, 2004); Andreas Becker, "Preußens schwarze Untertanen: 
in German territories, prompted in part by findings confirming that a significant share of the court personnel of African and Asian descent had been procured as slaves. New research has shown that like in many European countries, slavery was not only possible in German territories but in fact supported by specific laws and legal regulations. ${ }^{13}$ Since neither enslavement nor courtly employment were necessarily the final or only position of individuals of African or Asian provenance in Germany and Europe, their social, occupational, and spatial mobility merit further attention.

This study contributes to a more nuanced and non-dichotomous understanding of the historic non-white presence as well as to the social history of late eighteenthand early nineteenth-century (port) cities. It does so by analyzing employment strategies as well as job market positions of people of non-European descent in and around Hamburg during the study period. One central finding is that significantly more domestic workers of African and Asian origin entered Hamburg's wage labor market beginning in the 1790s. The study also argues that the employment-seeking practices of non-white laborers suggest they participated in cosmopolitan practices defined here as cross-cultural contacts, high intercultural competency, and the assertion of volition..$^{14}$

The primary source basis are advertisements documenting twenty-three instances of persons of non-European descent seeking employment and five instances of employers specifically seeking non-white personnel. They are the result of a thorough investigation of three newspapers combining methods of digital and manual research. Full text research was conducted for the Wöchentliche Nachrichten (1793-1849) and the Börsen-Halle (1801-1881) for the years 1793-1839 and 1801-1839, respectively. ${ }^{15}$ Manual research was required for the Hamburgische Addreß-Comtoir-Nachrichten (1767-1846) for the years 1767-1839. Although far more non-white workers lived in the city than

Afrikanerinnen und Afrikaner zwischen Kleve und Königsberg vom 17. bis ins frühe 19. Jahrhundert," Forschungen zur brandenburgischen und preußischen Geschichte 22, no. 1 (2012): 1-32.

13 Cf. Felix Brahm and Eve Rosenhaft, eds., Slavery Hinterland: Transatlantic Slavery and Continental Europe, 1680-1850 (Woodbridge, UK \& Rochester, NY: The Boydell Press, 2016); Rebekka von Mallinckrodt, "Verhandelte (Un-)Freiheit: Sklaverei, Leibeigenschaft und innereuropäischer Wissenstransfer am Ausgang des 18. Jahrhunderts," Geschichte und Gesellschaft 43 (2017): 347-380.

14 Similar definitions of cosmopolitan practices have been advanced for contemporary society by Ulf Hannerz, "Cosmopolitans and Locals in World Culture," Theory, Culture \& Society 7 (1990) 237-252, and for historical actors by Stefanie Michels, "Imperial, atlantisch, europäisch, kosmopolitisch? Globales Bewusstsein in Duala im frühen 19. Jahrhundert," in Bessere Welten: Kosmopolitismus in den Geschichtswissenschaften, ed. Bernhard Gißibl and Isabella Löhr (Frankfurt: Campus, 2017), 281-314.

15 For the digitized papers, search terms utilized were the German equivalents of "African," "Mulat*," "Negr," "Indian" (however, only the term currently applied to American Indians, Indianer, was useful, since the term used for South Asians, Inder, is the same as in der ("in the")), "slav ," "Moor," "Asian," as well as the more specific "Bushman," "Hottentot," and "Eskimo." The arguable bias of this selection was countervailed by the manual research, which largely confirmed the results of the first research phase. 
documented by these newspapers, the advertisements offer insights into occupational patterns that other sources do not. Advertisements as a basis for historical analysis have already been used fruitfully in scholarship on runaway slaves, missing persons, and criminals. These studies show that genre-specific attributes such as a relatively formulaic structure and anonymity can shed light on linguistic patterns and chronological clusters that in turn reflect shifts within intellectual and social phenomena. ${ }^{16}$

Job advertisements were a regular segment in Hamburg newspapers. They operated largely with recurring phrasal chunks specifying gender, employment preferences, skill sets, experience, recommendations, and sometimes the origin and age of employment seekers. Though a convention of minimal possible word count generally prevailed, there are a number of advertisements that deviate from this model by using differing formulations and providing additional information. Studies on advertisement papers and information offices suggest that while texts could be penned or dictated by job seekers themselves, many were written by clerks at the newspaper offices as modifications of a prototype. This is corroborated by the relative homogeneity of the Hamburg adverts. ${ }^{17}$ Independently operating employment agencies used papers to publicize candidates as well. They predominantly adopted existing language conventions and occasionally advertised several candidates in a single text, resulting in even more limited information about each employment seeker. Eight of the advertisements in this sample can be unambiguously linked to such agencies. ${ }^{18}$ The complex authorial process of seeking employment through agencies and newspapers means

16 Cf. Karin Sennefelt, "Runaway Colours: Recognisability and Categorisation in Sweden and Early America, 1750-1820," in Sweden in the Eighteenth-Century World: Provincial Cosmopolitans, ed. Göran Rydén (Farnham: Ashgate, 2013), 225-246; Sharon Block, Colonial Complexions: Race and Bodies in Eighteenth-Century America (Philadelphia: University of Pennsylvania Press, 2018). Potential problems are self-selection by pre-determined criteria and search terms as well as the recurring lack of biographical information.

17 Since few records of employment agencies or newspaper offices have survived, the precise authorship cannot be ascertained for each advertisement. Newspaper offices did not replace avenues of employment-seeking based on personal recommendation and small-scale agencies. However, as "early modern search engines," Adressbüros (offices of information) and advertising papers allowed for a less personal mode of looking for jobs. For general assessments of the practices of Intelligenzblätter (advertisement papers) in the region, cf. Anton Tantner, Die ersten Suchmaschinen: Adressbüros, Fragämter, Intelligenz-Comptoirs (Berlin: Klaus Wagenbach, 2015); Anton Tantner, “Adressbüros im Europa der Frühen Neuzeit" (habilitation thesis, Faculty of Historical and Cultural Studies, University of Vienna, 2011), accessed January 28, 2019, https://uscholar.univie.ac.at/get/o:128115, 177-181; Holger Böning, "Pressewesen und Aufklärung: Intelligenzblätter und Volksaufklärer," in Pressewesen der Aufklärung: Periodische Schriften im Alten Reich, ed. Sabine Doering-Manteuffel, Josef Mančal, and Wolfgang Wüst (Berlin: Akademie-Verlag, 2001), 69-119; Astrid Blome, "Das Intelligenzwesen in Hamburg und Altona," in Pressewesen der Aufklärung: Periodische Schriften im Alten Reich, ed. Sabine Doering-Manteuffel, Josef Mančal, and Wolfgang Wüst (Berlin: Akademie-Verlag, 2001), 183-207.

18 Cf. $A C N$, November 10, 1794, 703; $W N$, March 17, 1804, 6; $W N$, February 25, 1807, 6; $W N$, June 7, 1809, 6; $W N$, August 9, 1809, 6. Only three are collective advertisements, however: $A C N$, March 17, 1794, 175; ACN, July 15, 1799, 432; WN, September 28, 1837, 7. 
that the employment seekers themselves can be presumed to be co-authors of these texts at most, and these rather impersonal sources are therefore approached here with a prosopographical interpretation supplemented with microhistorical analysis, drawing on further archival material where possible.

In the following, this contribution first provides an overview of the advertising individuals in terms of their origins, sex, age, and chronological appearance, focusing specifically on indications of prior dependency and/or enslavement. It subsequently explores the role of non-white employees within the Hamburg labor market and outlines expectations placed on them in the publicized employment-seeking sector. Lastly, it examines individual strategies and patterns in non-white individuals' searches for jobs and discusses phenomena of mobility, multilingualism, and volition as cosmopolitan practices.

\section{Demographics of Non-European Employees on a Metropolitan Job Market}

Non-white seekers of wage work became visible in Hamburg newspapers from 1788 onward. Not a single such advert had appeared in the city's then only advertisement newspaper Addreß-Comtoir-Nachrichten from its first volume in 1767 until $1787 .^{19}$ From 1788 to 1798, there were a total of five such advertisements. They would become slightly more frequent in the twelve years between 1799 and 1810, though with eleven advertisements among hundreds, they were still extremely rare. ${ }^{20}$ In 1800, the first advert explicitly requesting a "Moor" servant appeared; the last advertisement looking for a non-white employee can be found in $1838 .{ }^{21}$ From 1811 to 1839, seven more advertisements by non-white people seeking employment were published. Considering the decline in overall advertisement publishing in one of the studied newspapers, this suggests that the presence of non-white persons on the wage labor market decreased slightly or perhaps remained stable. ${ }^{22}$

19 In isolated instances, non-white people had appeared in other forms, e.g. as missing persons, a phenomenon that will not be explored further in this contribution.

20 For most of the period of their publication, the Addreß-Comtoir-Nachrichten and the Wöchentliche Nachrichten appeared twice a week, featuring zero to five or more occupational advertisements per issue. For the $A C N$, the overall number of advertisements dropped precipitously after the paper's hiatus during the French occupation in the early 1810s. Thereafter, employment adverts were carried only occasionally and predominantly referred to well-paid positions.

21 Cf. $W N$, September 10, 1800, 73; WN, August 21, 1838, 7. Results for the search terms "Negro" and "African" are discussed below.

22 Considering the qualitative change in the source base, stability is more probable. 
Altogether, the presence of non-white workers correlates with long-term developments in the region, including Hamburg's increased participation in trade with North America and Caribbean free ports as well as the growing volume of the slave trade at the end of the eighteenth century. ${ }^{23}$ Some slaving voyages were even being outfitted in Hamburg and Altona. ${ }^{24}$ The publication chronology of the advertisements suggests a first peak around the turn of the century, at the height of Atlantic abolitionism, possibly indicating a link to the growing number of free individuals of African descent in the Americas. Significant economic disruptions affecting Hamburg in the years 1803 to 1814 , induced by the British Elbe river blockade (intermittently from 1803 to 1806) and the French occupation (November 1806 to May 1814), are only partially reflected in the sample. ${ }^{25}$ Economic activity resurged after 1815 , and the newly independent South American countries as well as regions in the Caribbean and along the Pacific littoral became frequent trade destinations. ${ }^{26}$

Most advertisements do not describe individual mobility paths. A place of origin is only indicated in seven advertisements, and even there mostly only vaguely. Besides the abovementioned Thomson, there are two other "Africans," one person from the Malabar region in southwest India, and three persons described as being from "America" and from the island of St. Thomas respectively. ${ }^{27}$ All other employees

23 These terms were also used to search digitized newspapers, but were corroborated by the results of manual searching of the ACN. For in-depth explorations of economic developments in the latter half of the eighteenth century, cf. Klaus Weber, Deutsche Kaufleute im Atlantikhandel 1680-1830: Unternehmen und Familien in Hamburg, Cádiz und Bordeaux, Schriftenreihe zur Zeitschrift für Unternehmensgeschichte 12 (Munich: Beck, 2004); Margrit Schulte Beerbühl, Deutsche Kaufleute in London: Welthandel und Einbürgerung (1600-1818) (Munich: Oldenbourg, 2007); Erik Gøbel, "Die Schiffahrt Altonas nach Westindien in der zweiten Hälfte des 18. Jahrhunderts," Jahrbuch // Altonaer Museum in Hamburg 28-31 (1995), 11-24. For a recent discussion of port cities, cf. Lasse Heerten, "Ankerpunkte der Verflechtung: Hafenstädte in der neueren Globalgeschichtsschreibung," Geschichte und Gesellschaft 43, no. 1 (2017): 146-175.

24 Cf. Magnus Ressel, "Hamburg und die Niederelbe im atlantischen Sklavenhandel der Frühen Neuzeit," WerkstattGeschichte 66//67 (2014): 75-96.

25 A possible reason for the continuous advertising during the French occupation is that advertisers may have frequently been persons who had been living in Europe for some years rather than recent arrivals. A notable shift is owed to the fact that publishing of the $A C N$ and $B H$ temporarily ceased between 1811 and 1814, thereby limiting the number of advertisement papers, cf. Blome, "Das Intelligenzwesen in Hamburg und Altona," 194. The ACN published significantly fewer advertisements after its relaunch.

26 For a general overview, see Hans-Dieter Loose and Werner Jochmann, eds., Hamburg: Geschichte der Stadt und ihrer Bewohner (Hamburg: Hoffmann und Campe, 1982); cf. also Annette Christine Vogt, Ein Hamburger Beitrag zur Entwicklung des Welthandels im 19. Jahrhundert: Die Kaufmannsreederei Wappäus im internationalen Handel Venezuelas und der dänischen sowie niederländischen Antillen (Stuttgart: Steiner, 2003), 42-51.

27 Cf. $A C N$, November 10, 1794, 703; WN, September 28, 1837, 7 (Africa), ACN, March 17, 1794, 175 (Malabar), $W N$, March 17, 1804, 6; WN, September 12, 1832, 6 (America), $W N$, July 16, 1822, 4 (St. Thomas). 
are referred to only in racialized terms, such as "Negro," "Moor," "Mulatto" or "Mulatta," or "Black." 28 The same applies to the non-white employees wanted in the five advertisements seeking workers. The reduced style of the newspapers likely encouraged such homogenizing labeling practices: The texts indicate that the specific origin of a servant was not essential information for future employers. Instead, his or her status as an identifiably non-white person was apparently more relevant.

Where places of origin are specified, some evoke connotations of slavery: Indian Malabar was the seat of several Dutch colonial forts, and the Caribbean island of St. Thomas was known for its transit trade in goods and humans. ${ }^{29}$ Job-seeker James Thomson's birthplace of "Congo" is likewise evocative in this regard. It may have referred to the Kingdom of Kongo, predominantly situated in today's Angola and a prime destination for European slavers during the early modern period and well into the nineteenth century. ${ }^{30}$ Whether Thomson had been enslaved at one point is unknown. His baptismal records reveal that there were two captains among his godparents. It is conceivable, though by no means unequivocally clear, that they purchased him as human cargo. ${ }^{31}$ In some ways, Thomson defies the typical characteristics - if they did in fact exist - of an enslaved captain's boy: He was of age when he arrived in Hamburg, he could name his parents, and he had a thorough enough sense of self to insist on keeping his (Anglophone) name upon being baptized. ${ }^{32}$ If he had previously been enslaved, he had learned by 1821 how to assert himself as an independent person.

28 There was only one additional advertisement mentioning a servant from St. Thomas without reference to descent or skin color. It stated that "[a] young person of 23 years, native of St. Thomas [aus St Thomas gebürtig] who very ably speaks French, Spanish, English, and Danish, also German quite well, can dress hair and shave, knows how to handle horses, and has the best attestations" wished to become a servant or horse attendant ( $A C N$, February 8, 1808). Due to its ambiguity regarding descent, this advertisement was not included in the sample.

29 The lack of information about the individuals' respective birthplaces leaves open the possibility that some of the advertisers may have been born in Europe.

30 See Daniel B. Domingues da Silva, The Atlantic Slave Trade from West Central Africa (Cambridge, MA: Cambridge University Press, 2017). "Congo" may also have referred to a general Central West African background or a speaker of Kikongo. The Anglophone name is rather surprising for a region with strong Portuguese influence.

31 The two captains were Carl Gustav Leopold Behn and Adrian Meyer, for whom research did not reveal obvious slavery connections. On the practice of captains purchasing enslaved people, cf. e.g. Karwan Fatah-Black and Matthias van Rossum, "Slavery in a 'Slave Free Enclave'? Historical Links between the Dutch Republic, Empire and Slavery, 1580s-1860s," WerkstattGeschichte 25, no. 66-67 (2015): 55-73.

32 See Hamburg State Archive, 512-4 A St. Katharinen Kirche, A XVII a 19 II Taufbuch 1816-1818: 273. The case of another person from "Congo" who arrived in Hamburg in 1820, only three years after Thomson's baptism, is quite different. According to contemporary reports, the child had been enslaved and taken to Brazil. There, a Hamburg merchant named Schlüter had purchased the boy and brought him to Hamburg, where he was baptized and christened Antonio Congo, later to receive schooling and vocational training in carpentry. He died in his thirties in northern Germany. Whether he and Thomson ever met is unknown, but it seems not entirely impossible. Cf. Renate Hauschild- 
Possible former enslavement, one may argue, could also be expressed as its linguistic reversal, for example by insisting that a person of African or Asian descent was "free." Such assertions of personal liberty appear in two advertisements published in 1802 and $1815 .^{33}$ Noticeably, the term "free" is found only in the collocation "[a] free Negro"; it is neither used in descriptions of racially unmarked persons nor in descriptions of persons labelled "Moors." Despite the small sample, this is no coincidence: Within American plantation economies, the term "Negro" was frequently used synonymously with "slave," creating and cementing the idea of African-descended persons as being enslavable by nature. ${ }^{34}$ Hamburg's elite keenly consumed reports on European colonies, and its merchants actively participated in trade with slave economies. Choosing the term "free Negro" arguably reflected a common cross-Atlantic understanding of race and racialized slavery. Despite these connections, however, the marker is not reliable as an indicator for an individual's former enslavement.

Similar to the provided information on origin and status, the gender ratio indicates but does not prove experiences of unfreedom. Judging from the use of gendered nouns and pronouns, only two non-white women appear in the advertisements, and they do so relatively late, in 1822 and $1832 .{ }^{35}$ Yet both women expressed the wish to be employed on journeys to "America" and "St. Thomas" respectively. ${ }^{36}$ The two women's stays in Europe seem to have been short; despite the change of employers, they took the form of intentionally temporary arrangements - a journey to Europe rather than a migration process. The peculiarity of their cases makes the dominance of male employees of non-European descent even more striking. What are its causes? One might argue that the imbalance suggests similarities to recruitment patterns observed for non-white and often enslaved court personnel. Scholarship has shown that trafficking networks supplying European courts during the seventeenth and eighteenth centuries strongly preferred males over females, and children and youths over

Thiessen, “Eine 'Mohrentaufe' im Michel 1855," Hamburgische Geschichts- und Heimatblätter 11, no. 1 (1982); Gabriele Lademann-Priemer and Ulf Priemer, "Antonio Congo - Ein Afrikaner in Norddeutschland im 19. Jahrhundert: Ein biografischer Versuch,” accessed February 1, 2018, http://www.glaubeund-irrglaube.de/texte/congo.pdf.

33 Cf. WN, November 24, 1802, 4; WN, August 17, 1815, 7.

34 Cf. Mark Häberlein, “'Mohren,' ständische Gesellschaft und atlantische Welt: Minderheiten und Kulturkontakte in der frühen Neuzeit," in Atlantic Understandings: Essays on European and American History in Honor of Hermann Wellenreuther, ed. Claudia Schnurmann and Hartmut Lehmann (Hamburg: Lit, 2006), 98-99; in more general terms David Brion Davis, Inhuman Bondage: The Rise and Fall of Slavery in the New World (Oxford \& New York, NY: Oxford University Press, 2006). The debate about the reciprocity of racism and Atlantic slavery is wide-ranging and cannot be explicated in full here.

35 Cf. $W N$, July 16, 1822, 4; WN, September 12, 1832, 6.

36 In the first case, a domestic servant wished to be employed on a return journey to a place of prior employment and perhaps community belonging. In the case of the second woman wishing to be employed on journey to St. Thomas, a similar context can be inferred. 
adults. ${ }^{37}$ On the other hand, male majorities are also characteristic of many forms of free migration. In addition, the fact that women were less visible in advertisements may reflect an interplay of socio-economic factors including stronger dependency, which could have limited their access to the free wage labor market and thus made their presence less visible to research. ${ }^{38}$

The strongest indicator for previous and perhaps continuing unfreedom of some individuals in the sample is the young age at which at least two of them had come to Europe. Published only seven months apart in 1794, two advertisements tell similar stories about people from very different backgrounds. In the first, "[a] Moor from the coast of Malabar, eighteen years old" reported that he could furnish "a good attestation from the gentleman who brought him along, whom he has served for seven years." ${ }^{39}$ In the second "[a] native African, who is twenty years old," recounts that he had "served in one position for nine years, [and] provides good attestations as well as expecting testimony of his honesty and loyalty from a reputable gentleman." ${ }^{40}$ Both men had been in some form of service from the age of eleven, i.e. at a significantly younger age than that of common apprenticeship in Hamburg at the time. ${ }^{41}$ One explicitly stated having been brought to Europe by a "gentleman," and a similar process can be inferred for the second. Case studies document that when young children were brought to Europe as dependent servants, they were often considered legal property. ${ }^{42}$ Even if no formal enslavement existed, the dependency engendered by young age was generally compounded by the effects of spatial removal and the severing of ties to the child's family

37 Kuhlmann-Smirnov, Schwarze Europäer im Alten Reich, 18-19 found only thirty-nine females in her sample of 311 court employees. Some of these women were wives and daughters of male staff members and not employed at court themselves. Heinrich Carl Schimmelmann, residing in Copenhagen, Hamburg, and Ahrensburg (near Hamburg), was notoriously involved in the trade of nonwhite children to European courts. Cf. ibid, 213; Christian Degn, Die Schimmelmanns im atlantischen Dreieckshandel: Gewinn und Gewissen (Neumünster: Wachholtz, 1974), 114-115.

38 Studying the Netherlands and France respectively, Jean Jacques Vrij and Pierre Boulle have suggested that on average, female non-white servants served a single family longer and that if enslaved, they were manumitted after longer periods of time than males. Cf. Jean J. Vrij, "Susanna Dumion en twee van haar lotgenoten: Drie Afro-Westindische vrouwen in achttiende-eeuws Amsterdam," Wi Rutu, Tijdschrift voor Surinaamse Genealogie 15, no. 1 (2015): 18-31; Pierre H. Boulle, "Slave and Other Nonwhite Children in Late-Eighteenth-Century France," in Children in Slavery through the Ages, ed. Gwyn Campbell, Suzanne Miers, and Joseph C. Miller (Athens, OH: Ohio University Press, 2009), 169-186. Whether these findings are applicable to German territories is uncertain.

39 ACN, March 17, 1794, 175.

40 ACN, November 10, 1794, 703. The fact that both men entered their positions as prepubescent children and left them as young adults may also indicate that they were no longer acceptable within the household as grown, sexually potent men.

41 The normal apprenticeship age was fourteen to fifteen, judging from advertisements. I have found only one other instance of a likely locally-born girl seeking employment as a household helper/babysitter at age eleven, cf. ACN, February 9, 1797, 98.

42 Cf. e.g. Fisher, Counterflows to Colonialism, 232-240. 
and society of birth. ${ }^{43}$ Yet the two young men advertising in Hamburg are unlikely to have been sent abroad for an education by their parents, as has been shown for a few other non-European children, since both clearly fulfilled servants' tasks. ${ }^{44}$

Assessing whether these servants came as enslaved persons or had previously experienced slavery is difficult in part because knowledge about processes of manumission in Germany and the conditions of the manumitted there is scarce. According to Ludwig Julius Friedrich Höpfner, one of the best-known and most influential lawyers in the second half of the eighteenth century, slaves in the German territories could be manumitted by oral agreement instead of a written declaration, which would account for the scarcity of written sources in this regard. ${ }^{45}$ As Orlando Patterson has pointed out, however, granting someone his or her freedom was a key element of slavery and of the mechanisms of societies with slaves. The possibility of manumission, he asserts, therefore needs to be understood as an instrument of control used by slave masters to enforce loyalty. Rather than severing the ties to their former enslavers, the post-manumission phase became one of continued dependency for the formerly enslaved, with new obligations placed upon them. ${ }^{46}$ Malabar, West Africa, and the Caribbean - the few known regions of birth of non-white servants in Hamburg - were deeply impacted by European slavery, and the presence of these workers in Europe must hence be understood as being entangled with

43 Cf. Patterson's now classic identification of "natal alienation" as an element of enslavement, Orlando Patterson, Slavery and Social Death: A Comparative Study (Cambridge, MA: Harvard Univ. Press, 1982), 35-76.

44 Where such placement did occur, its purpose was frequently - though not always - to provide for children of mixed European and African descent. Cf. Natalie Everts, “Brought up Well According to European Standards': Helena van der Burgh and Wilhelmina van Naarssen: Two Christian Women from Elmina," in Merchants, Missionaries and Migrants: 300 Years of Dutch-Ghanaian Relations, ed. Ineke van Kessel (Amsterdam: KIT, 2002), 101-109; Boulle, "Slave and Other Nonwhite Children in Late-Eighteenth-Century France"; on a later period, cf. Robbie Aitken, "Education and Migration: Cameroonian School Children and Apprentices in the German Metropole, 1884-1914," in Germany and the Black Diaspora: Points of Contact, 1250-1914, ed. Mischa Honeck, Martin Klimke, and Anne Kuhlmann (New York, NY \& Oxford: Berghahn, 2013).

45 Cf. Rebekka von Mallinckrodt, "Sklaverei und Recht im Alten Reich," In Das Meer: Maritime Welten in der Frühen Neuzeit, ed. Peter Burschel and Sünne Juterczenka (Cologne: Böhlau, forthcoming). Analogies to serfdom appear plausible but should be drawn with caution, since legal scholarship of the time drew an exacting line between the two forms of unfreedom. Serfdom was abolished in the Danish-Norwegian kingdom in 1804, while it continued to exist in Mecklenburg until 1822.

46 Cf. Patterson, Slavery and Social Death, 209-239. The literature on manumissions in the early modern period alone is vast. Cf. e.g. Rosemary Brana-Shute and Randy J. Sparks, eds., Paths to Freedom: Manumission in the Atlantic world (Columbia, SC: University of South Carolina Press, 2009) and Sue Peabody and Keila Grinberg, "Free Soil: The Generation and Circulation of an Atlantic Legal Principle,” Slavery \& Abolition 32, no. 3 (2011): 331-339 on the (non)application of the free soil principle in Europe. 
diasporic streams engendered by and connected to European expansionism and colonialism, even if the precise nature of that entanglement remains opaque. ${ }^{47}$

\section{Young, Employable, and Black: Perception and Social Position of Non-White Servants}

Among the large number of persons working as servants, people of African and Asian descent stood out only in certain respects. Their range of possible positions was narrower and, it appears, more rigidly prescribed than that of Europeans. In the sample, lower-paid domestic work predominates, and emphasis is placed on youth and outward appearance imbuing Black bodies with value by way of exoticism and physical strength. Like others, non-white workers are presented as desirable service sector employees - and in some regards, they catered to the representative needs of future employers more obviously than European-descended servants.

The types of occupations sought by non-white laborers in Hamburg are strikingly homogeneous: Of the eighteen advertisements naming desired occupations, fifteen were applications to be a servant, sometimes in conjunction with alternatives. ${ }^{48} \mathrm{~A}$ waiter, a valet, and a nursemaid also appear. ${ }^{49}$ In one case, a person sought employment either as a servant or a Tafeldecker (waiter); a willingness to do any service work was expressed in two advertisements. ${ }^{50}$ As qualifying skills, three of the adverts mention hair-dressing, six the ability to wait on employers (Aufwartung, Servieren). ${ }^{51}$

47 Coined by George Shepperson in the 1960s, the African diaspora concept has been widely adopted; as an approach, it tends to emphasize collective cultural production by succinct groups. Models produced in the 1990s influenced by postcolonial scholarship increasingly highlighted hybridity of culture and identity. Cf. Ira Berlin, "From Creole to African: Atlantic Creoles and the Origins of African-American Society in Mainland North America," The William and Mary Quarterly 53, no. 2 (1996): 251-288; Paul Gilroy, The Black Atlantic: Modernity and Double Consciousness, reprinted. (London: Verso, 1999). For a critical appraisal, cf. Patrick Manning, “Africa and the African Diaspora: New Directions of Study,” The Journal of African History 44, no. 3 (2003): 487-506.

48 Cf. $A C N$, March 17, 1794, 175; ACN, November 10, 1794, 703; ACN, July 15, 1799, 432; ACN, December 23, 1799, 800; $A C N$, December 4, 1806, 759; $W N$, February 25, 1807, 6; $W N$, June 7, 1809, 6; $A C N$, August 7, 1809, 487; WN, August 9, 1809, 4 [these last two possibly referring to the same person]; $A C N$, February 5, 1810, 87; $W N$, February 7, 1810, 6 [these two perhaps also referring to the same person]; WN, August 17, 1815, 7; WN, July 16, 1822, 4; WN, September 28, 1837, 7; ACN, March 7, $1839,4$.

49 Cf. $W N$, August 9, 1809, 4 (waiter); $A C N$, December 21, 1797, 799 (valet); WN, September 12, 1832, 6 (nursemaid).

50 Cf. $W N$, August 9, 1809, 4; ACN, December 21, 1797, 799; ACN, December 23, 1799, 800.

51 Cf. $A C N$, November 10, 1794, 703; $A C N$, December 21, 1797, 799; WN, February 25, 1807, 6. Aufwartung: $A C N$, November 10, 1794, 703; ACN, December 21, 1797, 799; ACN, July 15, 1799, 432; ACN, December 4, 1806, 759; WN, July 16, 1822, 4. 
Two men claimed writing skills, ${ }^{52}$ and James Thomson and a young man from Malabar were listed as possessing aptitude in handling horses. ${ }^{53}$ More unusually, the earliest advertisement in the sample, published in 1788, highlighted the respective person's ability to play the piano and sing, perhaps envisioning employment in a capacity other than that of servant. ${ }^{54}$ One advertisement mentions possible occupation as "StaatsMohr" (state Moor), a variation of the aristocratic employment of non-white people for prestige reasons. ${ }^{55}$ The majority of qualifications thus corresponded to conventionally required servant skills, including the ability to shave and dress hair and, occasionally, to be able to write and serve at the table. ${ }^{56}$ Hence while the examined advertisements by people of non-European descent reflect a significant degree of occupational training as well as some formal learning, they overall do not point to apprenticed or academic training.

Yet advertisements placed by or offering work to people of non-European descent differed from the average job adverts in the strong emphasis placed on outward appearance and biological factors such as age. ${ }^{57}$ Of the twenty-three advertisements placed by people identified as non-white, eight persons are indicated to be "young." For six of them, the ages eighteen, twenty (twice), twenty-five, twenty-six, and twenty-eight years are given, while two are simply described as "young." 58 In one text, the job-seeker's youth is linked to a positive aesthetic evaluation of his physique: He is, the advertisement asserts, a "well-formed Negro, tall for his age." 59 The fact that two servants of African respectively South East Asian birth claimed that they had been employed from the age of eleven is particularly striking since, as explained above, few prepubescent children appeared in job advertisements in the researched period. In

52 Cf. $A C N$, November 10, 1794, 703; ACN, December 4, 1806, 759.

53 Cf. $A C N$, March 17, 1794, 175; WN, May 17, 1821, 6.

54 Cf. $A C N$, September 4, 1788, 552.

55 Cf. WN, March 17, 1804, 6.

56 The job description Bedienter, predominantly in its male form, left room for numerous tasks and allowed for transitions into other realms of service, e.g. into a more prestigious chamberlain position. Some people applied to be either servants or valets, cf. e.g. ACN, August 3, 1786, 480 and elsewhere. Other related professions were Reitknecht (horse attendant), Marqueur (servant at a coffee house or billiard saloon), Hausknecht (manservant for menial and business-related tasks), and Küper (storehouse worker, taking on the meaning of port inspector).

57 Even the outward appearance of presumably European male servants was sometimes referenced, e.g. in remarks that the men were "beautiful in stature," "well-grown," or "handsome;" such statements were comparatively rare, however. Cf. ACN, December 21, 1801, February 22, 1770, January 9, 1783 and elsewhere.

58 Cf. ACN, March 17, 1794, 175; ACN, November 10, 1794, 703; ACN, March 7, 1839, 4; WN, August 9 , 1809, 49; $W N$, May 17, 1821, 6; $W N$, November 24, 1802, 4; $W N$, June 7, 1809, 6; $W N$, September 28, 1837, 7. The likely double of the August 9, 1809 advertisement, ACN, August 7, 1809, 487, also lists its subject as being 25 years old.

59 ACN, December 21, 1797, 799. It should be noted that the term wohlgebildet may imply being "well-formed" in a physical or in an educational sense. 
advertisements placed by prospective employers, descriptors of age and appearance feature dominantly as well. More than anything else, they are indicative of expectations formed in regard to non-white bodies.

Each of the five advertisements seeking non-white employees mentions nonEuropean appearance prominently. One specifies "a Moor aged sixteen to twentyfour years," another "a young Moor," and an 1824 advertisement calls for a "young pretty real Moor or Moor boy."60 A collective call placed in 1838 lists "one Moor (fourteen to sixteen years old) as a servant." ${ }^{61}$ Here, as with European servants, the limited age range requested may hint at the positions being temporary or embedded in life-cycle employment transitions. Furthermore, youth, male gender, and Blackness are evoked to conjure up an aesthetic of luxury and worldliness. Although vague in its actual demands, this exoticism seems to have been generally understood by the papers' readers. ${ }^{62}$

What would the described racial terminology have meant to Hamburg readers of the period? Neither "Moor" nor "Negro," terms used in eighteen of the advertisements placed by job-seekers and in all five texts requesting non-white employees, were unambiguously defined classifications in eighteenth-century German-speaking territories. ${ }^{63}$ Both could be applied to people of (South) Asian as well as to people of African descent. The term "Moor" carried associations with Spanish-Moorish nobility and was preferentially used in a court context. Conversely, "Negro" was associated more closely with the transatlantic plantation economy. ${ }^{64}$ To some degree, choosing the word "Moor"

$60 W N$, October 21, 1819, 5; WN, September 10, 1800, 6; WN, March 15, 1824, 5. It is noteworthy that a "real Moor" is requested in one advertisement. In his contribution to this volume, Walter Sauer suggests that people with a somewhat darker skin tone had become so common in Austria that only very dark-skinned persons still held what might be called an exotic appeal at a certain point.

61 Cf. WN, August 21, 1838, 7.

62 Similar to Französin, Mohr may have been understood to be a type of occupation rather than simply a descriptor of ethnicity. This theory is supported by the fact that only one text searching for a "Moor" employee actually specified a skill, namely the ability to handle horses and speak passable German or French. Cf. WN, October 21, 1819, 5.

63 "Moor" was used ten times in advertisements by persons seeking employment, while "Negro" was used in two advertisements appearing in the same issue, namely ACN, December 21, 1797, 799, as well as in $W N$, November 24, 1802, 4, in $W N$, August 17, 1815, 7, and in $W N$, May 17, 1821, 6. "Negress" was used in WN, September 12, 1832, 6. "Mulatto" and "Mulatta" each appeared only once, “African” appeared twice, cf. $A C N$, December 23, 1799, 800; $W N$, July 16, 1822, 4; $A C N$, November 10, 1794, 703; WN, September 28, 1837, 7 respectively. "Black" appeared once, in ACN March 7, 1839, 4. 64 Cf. Häberlein, “'Mohren,' ständische Gesellschaft und atlantische Welt”; James H. Sweet, “The Iberian Roots of American Racist Thought," The William and Mary Quarterly 54, no. 1 (1997): 143-166. Though the terms have fallen out of use in German recently, both Mohr and Neger now strongly (and pejoratively) connote people of African descent. The Hamburg sources, however, also regularly apply both terms to persons from South Asia. Newspaper reports on foreign events used Mohr in reference to North Africans, but usually not in reference to people of African descent in the Americas. 
thus tapped into semi-positive associations evoking the exoticism of "court Moors" and perhaps positioned applicants advantageously on the job market. It is doubtful, however, whether these words constituted identity-shaping categories for the individuals to whom they were applied, and it is unknown whether they used the same terminology themselves.

Aestheticizing combinations of appearance, ethnicity, and age contrast with different, yet no less salient expectations linked to Black bodies expressed in an 1807 advertisement. The text diverges from the rest of the sample with its distinct requirements and unusual intentions. In it, a person referred to as "Economic Councilor [Oeconomie-Rath] Meyer in W . . . d . . g. proposes his plan "to lay out a plantation of American tobaccos," for which purpose he "desire[s] to employ a few workers, especially strong healthy Negroes and Negresses who must have worked in such tobacco plantations in North America." ${ }^{\circ 5}$ The text leaves open who exactly Meyer was and whether he intended to set up his agricultural experiment in Germany or the Americas. ${ }^{66}$ These uncertainties notwithstanding, it is obvious that he believed workers of African descent to possess a specific expertise with regard to tobacco - one based on physique as well as on work experience he presumed to be characteristic for workers of African ancestry.

Implicitly connected to Meyer's association of “Negroes” with plantation work is an assumption that lay at the core of early modern chattel slavery: Staple crop plantations in the Americas were overwhelmingly farmed by enslaved people, a practice based partly on the idea that African bodies were physically stronger, less sensitive to pain, and thus more suited to excruciating work. ${ }^{67}$ Meyer, who promised "favorable conditions," 68 was apparently not planning to enslave his workers but was keenly aware of the fact that growing tobacco in the Americas depended heavily on enslaved labor.

Did Meyer also assume that he would reach a substantial number of not just African-descended people but actual former plantation laborers by advertising in Hamburg newspapers? Perhaps he had been inspired by a report published seven years

$65 W N$, April 4, 1807, 8.

66 The most likely candidate is Hannover-born Georg Friedrich Wilhelm Meyer (1782-1856), who became a botany professor in Göttingen later in life. He seems to have lived around Hannover in the years 1805 to 1808, but his extensive works barely make mention of tobacco. This may indicate either that his experiment never came to fruition or that the advertiser was a different Meyer to begin with. Cf. Klaus-Dirk Henke, “Georg Friedrich Wilhelm Meyer, 1782-1856: Botanik, Ökonomie,” in Göttinger Gelehrte: Die Akademie der Wissenschaften zu Göttingen in Bildnissen und Würdigungen, 1751-2001, ed. Karl Arndt, Gerhard Gottschalk, and Rudolf Smend (Göttingen: Wallstein, 2001); 144. European-grown tobacco sold in Hamburg was rare and usually came from Mecklenburg, cf. ACN, January 20, 1777, 48; Mary Lindemann, Patriots and Paupers: Hamburg, 1712-1830 (New York, NY: Oxford University Press, 1990), 43.

67 Cf. Sweet, “The Iberian Roots of American Racist Thought,” 157-164.

$68 W N$, April 4, 1807, 8. 
earlier by the Hamburg Poor Relief stating that there were thirty-three "homeless Negroes" among its impoverished charges. ${ }^{69}$ Hospital records suggest, however, that many of these thirty-three individuals were in fact unemployed Indian sailors rather than former enslaved field workers from America. Perhaps Meyer did not know this, or perhaps he had other persons in mind, as non-white persons documented in newspaper advertisements were only a minority of the total non-white population in the region. At any rate, agricultural labor was not mentioned as a desired occupation in any of the other examined advertisements. Taking into account the lack of any evidence to the contrary, it seems likely that Meyer's experiment remained unsuccessful.

Meyer's plantation scheme was unusual in that it called for physical ability and agricultural expertise. Other adverts seeking non-white domestic workers generally placed more value in the perceived exotic outward appearance than was customary for European servants. Non-white domestic servants advertising their own skills in newspapers also tended to be young, a characteristic they emphasized more frequently than their white counterparts. In terms of the tasks performed by these servants, there appears to have been little difference between white and non-white persons. As will be explored in the next section, however, advertisements focusing on workers of non-European descent indicated above-average mobility and wideranging language skills.

It is difficult to assess whether the documented laborers were able to draw benefits - in monetary compensation or occupational opportunities - from tailoring their skills to employers' needs or from the representational appeal of their bodies. In general, Hamburg polemics ascribed a high degree of self-determination to domestic servants and spoke of their willingness to change employers frequently if unsatisfied. ${ }^{70}$ At the same time, servants were also perceived as a troubled and troublesome part of the population, threatened by poverty and - in the eyes of many contemporary writers - by their own overspending. ${ }^{71}$ While servants thus remained a socially vulnerable group especially during times of economic crisis, it is plausible to assume

69 Lindemann, Patriots and Paupers, 149, quoted from Caspar Voght, "Acht und zwanzigste Nachricht an Hamburgs wohlthätige Einwohner über den Fortgang der Armenanstalt," in Nachrichten von der Einrichtung und dem Fortgang der Hamburgischen Armen-Anstalt, vol. 1 (Hamburg: Hoffmann, 1794), 269-272.

70 Cf. Christian Ludwig Grießheim, Verbesserte und vermehrte Auflage des Tractats: die Stadt Hamburg in ihrem politischen, öconomischen und sittlichen Zustande: Nebst Nachträgen zu diesem Tractate; und Beyträgen zu der Abhandlung: Anmerk. u. Zugaben über den Tractat die Stadt Hamburg, welche selbigen ebenfalls verbessern und gewisser machen (Hamburg: Drese, 1760), 230-234.

71 These concerns surfaced particularly during the establishment of the Hamburg Poor Relief in 1788, cf. Lindemann, Patriots and Paupers; Caspar Voght and Johann A. Günther, "Zwei Aufsätze über Quellen der Verarmung, im Namen des Hamburgischen Armen-Collegiums entworfen," in Schriften und Verhandlungen der Gesellschaft zur Beförderung der Künste und nützlichen Gewerbe, vol. 1 (Hamburg: Carl Ernst Blohn, 1792), 392. 
that wherever possible, male and female as well as non-white and white servants used their bargaining power and the possibility to change employers to attain better working conditions. ${ }^{72}$

\section{Mobility, Multilingualism, and Volition: Practices of Cosmopolitan Employment Seeking}

James Thomson, whom we encountered at the beginning of this contribution, mentioned five life stations in the short description of his path in his advertisement. Born in "Congo," he had lived in Hamburg, then moved to two other towns before returning to the port city. Four years earlier, his baptism had been noted in a newspaper only in passing: ${ }^{73}$ In the church records, the event is marked by a few lines mentioning the candidate's age, his place of birth, and the names of his parents: James and Maria Thomson. He had had four instead of the usual three godparents: Anna Margaretha Kasang, wine merchant Meyer, and the two mentioned ship captains. ${ }^{74}$ Although adult baptisms, and especially those of non-Europeans, remained a rare occurrence even in 1817, his was not one of the highly publicized "Moor baptisms" fashionable at noble courts during the seventeenth and eighteenth centuries. ${ }^{75}$ Yet despite the relative simplicity of the ceremony, Thomson's advertisement suggests that the young man had made an impression on local society. The reference to his name and baptism seem to indicate an expectation to be recognized upon his return to Hamburg.

Besides Thomson, "Francois Michel Batist" was the only non-white person to use their name in an advertisement. Having just arrived in Hamburg from Stockholm in the service of a gentleman, the "Moor" Batist placed an advertisement in August 1805. He had recently become unemployed, either through loss of his position or upon having reached the end of a temporary arrangement. While looking for a new position, he stayed at the König von England, a prominent hotel, perhaps still with his former employer. Like Thomson's, his presentation was that of a worldly man: He claimed to

72 Cf. Gotthard Frühsorge, Rainer Gruenter, and Beatrix Wolff Metternich, eds., Gesinde im 18. Jahrhundert (Hamburg: Meiner, 1995). Unlike most other German territories, Hamburg did not issue a formalized Gesindeordnung, a mandatory code of conduct that served to police servant behavior and curtail wages, until 1875.

73 Cf. $W N$, October 24, 1817, 11.

74 Whether one of the captains' ships was the vessel that brought Thomson to Europe is unclear. Hamburg State Archive, 512-4 St. Katharinen Kirche, A XVII a 19 II Taufbuch 1816-1818: 273. The church record states his age as twenty-four, whereas the advertisement almost four years later lists him as twenty-six.

75 Stylized as exotic, performative acts, they were intended to evoke Christian universalism and prestigious worldliness. Cf. Kuhlmann-Smirnov, Schwarze Europäer im Alten Reich, 175-177. 
speak "English, French, Spanish, Italian, Swedish, and Danish" and stated that he sought employment "here or on a journey."76

Both Batist and Thomson displayed practices and self-representational tools that emphasize their competence in interacting with relative strangers. As is true for the majority of individuals in the sample, mobility and multilingualism were central to their professional presentation. Similar to Batist's, many of the advertisements also record servants' preferences as drivers for their mobility and their interaction with strangers. These choices and practices suggest that non-white servants participated in processes more complex than that of professional and personal "integration" into local communities: ${ }^{77}$ They evoke an image of cosmopolitan subjects navigating an increasingly interconnected world. ${ }^{78}$

Whether or not the concept of cosmopolitanism can meaningfully be applied to non-Europeans on the one hand and people of lower-class status on the other hand is still controversially debated among academics. ${ }^{79}$ Africa historian Stefanie Michels has recently used the provocative power of the term "cosmopolitan" when applied to non-white persons to study the West African Duala. Working on individuals who left little in the way of written records, she has made a case for operationalizing cosmopolitanism along three criteria. In analogy to Michels' definition, I argue that the practices of non-European servants in the Hamburg area can be understood as cosmopolitan along three axes: a) contacts to people from diverse linguistic, cultural,

$76 W N$, August 31, 1805. The spelling of Batist's name in corrupted French is taken directly from the source.

77 See footnote 13. Cf. Kuhlmann-Smirnov, Schwarze Europäer im Alten Reich, chapter IV.

78 Newspapers facilitated interconnectedness. Catering to a broad hinterland and to a nonregional market, they were instrumental in connecting the city to the wider world. Yet while servant registries from the 1830s show that most servants were locally bound and stayed with one employer for years or even decades, the newspaper advertisement section made those who specialized in mobility highly visible. Not surprisingly, calls for domestic and other workers came from as far away as Sweden, southern Europe, and occasionally the Caribbean. Cf. ACN, March 14, 1785, 168 (Französin, Sweden); ACN, July 5, 1779, 408 (office clerk, Spain); ACN, January 19, 1784, 47-48 (female servant, Caribbean). At least in their self-presentation, these servants were proficient in several languages and had either just arrived from journeys or were applying for a position "on travels" (auf Reisen), as stated in a common phrase. They were frequently persons born outside of Hamburg - in Russia, England, Norway, or France. To some degree, the following statements might thus be likewise applicable to a section of European servants. A rough estimate suggests that around one fifth to one fourth of advertisements were for servants, while the rest was for clerks, apprentices, male and female cooks, nursemaids, ladies' companions, gardeners, and so forth.

79 Cf. e.g. Bernhard Gißibl and Isabella Löhr, eds., Bessere Welten: Kosmopolitismus in den Geschichtswissenschaften (Frankfurt: Campus, 2017); Steven Vertovec and Robin Cohen, eds., Conceiving Cosmopolitanism: Theory, Context, and Practice (New York: Oxford University Press, 2002); Pnina Werbner, "Vernacular Cosmopolitanism," Theory, Culture \& Society 23, no. 2-3 (2016): 496-498. Historical works dealing with cosmopolitanism or cosmopolitan phenomena abound; for Hamburg, cf. e.g. Peter U. Hohendahl, ed., Patriotism, Cosmopolitanism, and National Culture: Public Culture in Hamburg 1700-1933 (Amsterdam: Rodopi, 2003). 
and ethnic backgrounds through mobility or social association; b) the ability to navigate diversity by developing skills and proficiency in languages; and c) an affirmative attitude toward encountering diversity as displayed in statements or acts. ${ }^{80}$

On average, servants of non-European descent were a highly mobile group, as evidenced by the direct references made to prior travels. Some individuals who placed advertisements had accumulated considerable experience in this regard by the time of publication. Not only Thomson and Batist detailed their place(s) of former employment; another young man was described as having previously "accompanied a gentleman on travels," 81 and a woman who desired to go back to "America" had only recently arrived from there in the company of her employer's family according to her advert. ${ }^{82}$ While her stay seems to have been short, the opposite was true for a man advertising in 1799 who "had already been in Europe for eighteen years." ${ }^{83}$ In fact, the figure of the extremely mobile African-descended person can be found in other written works as well. In a 1795 treatise on smallpox, author Francisco Gil evoked a "Negro who spends one year in Hamburg, afterward the 2nd and 3rd year in Berlin, the 4th in Dresden, the 5th in Hannover, then returning after a four-year-absence to Hamburg." 84 Though the Spanish author's problematic use of Africans as an embodiment of the spread of disease peddled racist stereotypes and was disputed by a reviewer, his image of Black mobility - albeit only within German-speaking territories - was not faulted. ${ }^{85}$

Mobility and its competent navigation are likewise apparent in the frequent mention of language abilities. Fourteen of the twenty-three advertisements placed by people of African and Asian descent in the sample mention such language skills, which were presumably acquired in their respective regions of origin, during employment, or through formal training. Almost every one of them claimed to speak at least two languages, and with the exception of two, all spoke at least "a little" German. ${ }^{86}$ Other frequently mentioned language skills are French in nine cases, English in eight

80 Cf. Berlin, "From Creole to African," 254; Hannerz, "Cosmopolitans and Locals in World Culture”; Michels, “Imperial, atlantisch, europäisch, kosmopolitisch?”, 284-287.

$81 W N$, February 7, 1810, 6; ACN, February 7, 1810, 87. Thomson's and Batist's advertisements are identical to the latter except for the former two containing an additional clause referencing language skills and experience in Aufwartung.

82 Cf. $W N$, September 12, 1832, 6.

83 ACN, December 23, 1799, 800. The fact that the advertisement referred to Europe rather than just Germany likewise indicates a transnational scope of movement during this time.

84 Francisco Gil, Anweisung zu einer sichern Methode, die Völker vor den Blattern zu bewahren, und dadurch die gänzliche Ausrottung dieser Krankheit zu erlangen. Nebst kritischen Betrachtungen, auf Befehl der Regierung zu Quito in Peru über diese Methode angestellt, vom Doctor Santa Cruz E. Espejo (Leipzig: Paul Gotthelf Kummer, 1795), xviii-xix. It is not clear how familiar the Spanish author was with Hamburg, but he uses it as an argumentative case throughout.

85 Cf. Anonymous, "No title [Review of four treatises on smallpox]," Medicinisch-chirurgische Zeitung 2, no. 51 (June 1795): 457-458.

86 Cf. $A C N$, December 21, 1797, 799; WN, March 17, 1804, 6. Besides Batist, a 20-year old man advertising in 1839 did not claim to know German; cf. ACN March 7, 1839, 4. One person from Malabar 
cases, and Danish in five cases. Italian, Spanish, Swedish, and (in one case) unspecified "several languages" 87 also make an appearance. On average, people of nonEuropean descent advertising in Hamburg spoke more than three languages, ${ }^{88}$ with some individuals far exceeding this average. There was a former chamberlain who claimed to speak "Dutch, English, French, and a little German," 89 and of course Batist with his knowledge of six languages. Proficiency in German suggests that most of the men and women must have lived in German-speaking territories or with Germanspeaking employers for some time. Mastering a language undoubtedly expanded a person's scope of action in an otherwise foreign country, ${ }^{90}$ and language skills also increased an individual's value as a domestic employee since multilingual servants could function as interpreters, informal language teachers, and prestigious companions for young traveling gentlemen and - less commonly - ladies. ${ }^{91}$ To underline such abilities would therefore have likely increased the advertiser's prospects for employment and may have resulted in higher salaries. Assuming employment seekers only mentioned the languages that might be of interest to their European employers, we may presume that some spoke one or more additional African or Asian languages as well.

Notably, a desire to travel is explicitly expressed in eight of the twenty-three investigated advertisements placed by people of non-European descent. ${ }^{92} \mathrm{~A}$ typical phrasing of such a wish was put forth by a young man who stated his willingness to work "in the city or on travels." 93 Three adverts even mention specific destinations:

only mentions German. Having lived in India for some years, he presumably also spoke a local language. Cf. ACN, March 17, 1794, 175.

$87 W N$, June 7, 1809, 6. There may have been African languages among them. There are documented cases in which African children were supposed to be trained as interpreters for EuroAfrican trade, cf. Boulle, "Slave and Other Nonwhite Children in Late-Eighteenth-Century France."

88 Rounded down from 3.21 if the man from Malabar is counted as bilingual and the "several languages" are counted as two.

89 Cf. ACN, December 21, 1797, 799.

90 The practice of placing a newspaper advertisement is itself indicative of linguistic plasticity. It conventionally entailed finding one's way to the office, communicating with the clerk, providing adequate data, and receiving and replying to responses, cf. Tantner, Die ersten Suchmaschinen, 83-118.

91 Cf. Ulrike Krampl, "Fremde Sprachen: Adelserziehung und Bildungsmarkt im Frankreich der zweiten Hälfte des 18. Jahrhunderts," in Militär und Mehrsprachigkeit im neuzeitlichen Europa, ed. Helmut Glück and Mark Häberlein (Wiesbaden: Harrassowitz, 2014), 97-112. Multilingualism, especially for the European early modern period, is best researched for the merchant and upper classes, but authors acknowledge that it could be found among lower classes as well, albeit with less historical evidence, cf. Helmut Glück, Mark Häberlein, and Konrad Schröder, Mehrsprachigkeit in der frühen Neuzeit: Die Reichsstädte Augsburg und Nürnberg vom 15. bis ins frühe 19. Jahrhundert (Wiesbaden: Harrassowitz, 2013), 4-5.

92 Considering that two advertisements mentioned persons of non-European descent with five words or less, there may have been more who hoped for such employment.

$93 W N$, June 7, 1809, 6; cf. also ACN, December 4, 1806, 759 for a near-identical statement. 
Beside the two women (presumably) returning to the American continent, there is the 1797 case of a young man who stated that he would like to go "on travels, preferably to England." 94 Considering the very real possibility of enslavement for nonEuropean servants in early modern Germany, such expressions of volition provide an important counter-narrative. They raise questions about alternative or multiple sites of community belonging and servants' agency.

Although non-white mobility did not take place in a power vacuum, the sample of advertisements shows that servants of African and Asian descent frequently opted for a more rather than less cosmopolitan way of shaping their lives. In doing so, they acquired skills that enabled them to navigate the free wage labor market and exert considerable control over their occupational path. Since their backgrounds seem to have varied, the question whether or not these phenomena are indicative of a "cosmopolitan consciousness" 95 cannot be answered conclusively. Yet curiosity about the world in general and a genuine openness toward encounters with people from other cultures should not be excluded as plausible motives for young men and women of non-European descent during the eighteenth and nineteenth centuries. ${ }^{96}$ Applying concepts of cosmopolitanism to case studies of non-white individuals thus adds important aspects of understanding regarding their itinerant lives.

\section{Conclusion}

This contribution has shown that servants of non-European descent formed a visible segment of the Hamburg servant labor force. Expectations regarding them seem to have carried over partially from a court context to Hamburg's urban setting. Scholarly consensus holds that in Germany, non-white and sometimes enslaved servants were a phenomenon associated with noble courts much longer than in European countries with long-term colonial possessions. ${ }^{97}$ In the Hamburg region during the late eighteenth and early nineteenth century, however, they appeared as free laborers

94 Cf. $A C N$, December 21, 1797, 799; WN, July 16, 1822, 4; WN, September 12, 1832, 6.

95 Michels, “Imperial, atlantisch, europäisch, kosmopolitisch?”, 304.

96 Analysis of ego documents such as slave narratives can provide a valuable comparative perspective here, cf. Ifeoma Kiddoe Nwankwo, Black Cosmopolitanism: Racial Consciousness and Transnational Identity in the Nineteenth-Century Americas (Philadelphia, PA: University of Pennsylvania Press, 2005) and the now classic Olaudah Equiano, The Interesting Narrative of the Life of Olaudah Equiano: Written by Himself, 9th ed. (London: self-published, 1794).

97 Whether the increased influx of non-Europeans created a "supply" beyond the social networks of courts or whether the port city and its merchant connection had long drawn non-white employees is up for debate. For the Austrian case, cf. Christine Sulzbacher, "Beten - dienen - unterhalten: Zur Funktionalisierung von Afrikanern und Afrikanerinnen im 19. Jahrhundert in Österreich," in Von Soliman zu Omofuma: Afrikanische Diaspora in Österreich 17. bis 20. Jahrhundert, ed. Walter Sauer (Innsbruck: Studienverlag, 2007), 100. 
characterized by above-average spatial mobility, language skills, and an expressed preference for non-local employment.

The reasons for the migration of these workers and their personal backgrounds remain largely veiled, and the sample analyzed here leaves various other questions unanswered as well: How did Asians, Africans, and other people of non-European descent experience their time in Hamburg? Did they interact with other persons of similar background? To what extent were they able to establish and maintain local or cross-continental communities? ${ }^{98}$

Despite the limited availability of personal voices, the sample brings to the fore distinct patterns of non-white employment: Likely composed of formerly enslaved persons as well as freeborn labor migrants, non-white servants appear to have navigated an uncertain status as domestic workers and made strategic employment decisions. Describing these practices as cosmopolitan does not deny the existence of structural inequalities and unfavorable conditions, but rather provides a tool facilitating our understanding of the choices and variegated experiences of people of African and Asian descent. Beyond the perpetual exceptionality of a historic non-white presence in Europe, and beyond the ostracism vs. integration debate, the sources show that people of African and Asian descendance forged transnational connections and played a visible and active role in European societies of their time.

\section{References}

\section{Archival Sources}

Hamburg State Archive. 512-4 St. Katharinen Kirche. A XVII a 19 II Taufbuch 1816-1818.

\section{Printed Sources}

Anonymous. "No title [Review of four treatises on smallpox]." Medicinisch-chirurgische Zeitung 2, no. 51 (June 1795): 449-464.

Börsen-Halle. (From November 15, 1805: Mit allergnädigstem Kayserlichen Privilegio. Börsen-Halle; from 1806 Privilegierte Liste der Börsen-Halle; from 1825: Liste der Börsen-Halle; from July 2, 1827: original title). Hamburg: Conrad Müller et al. Vol. 1801-1839.

Equiano, Olaudah. The Interesting Narrative of the Life of Olaudah Equiano: Written by Himself. 9th ed. London: self-published, 1794.

98 For a similar enquiry, cf. Ponte, “'Al de swarten die hier ter stede comen'.” To answer these questions in the Hamburg context, other types of sources will be investigated in my dissertation project at the University of Bremen. 
Gil, Francisco. Anweisung zu einer sichern Methode, die Völker vor den Blattern zu bewahren, und dadurch die gänzliche Ausrottung dieser Krankheit zu erlangen. Nebst kritischen Betrachtungen, auf Befehl der Regierung zu Quito in Peru über diese Methode angestellt, vom Doctor Santa Cruz E. Espejo. Leipzig: Paul Gotthelf Kummer, 1795.

Grießheim, Christian Ludwig. Verbesserte und vermehrte Auflage des Tractats: die Stadt Hamburg in ihrem politischen, öconomischen und sittlichen Zustande: Nebst Nachträgen zu diesem Tractate; und Beyträgen zu der Abhandlung: Anmerk. u. Zugaben über den Tractat die Stadt Hamburg, welche selbigen ebenfalls verbessern und gewisser machen. Hamburg: Drese, 1760. Hamburgische Addreß-Comtoir-Nachrichten. Mit allergnädigstem Kayserlichen Privilegio. (From 2 Feb 1826: Hamburgische Neue Zeitung und A[d]dreß-Comtoir-Nachrichten). Hamburg: Dietrich Anton Harmsen et al. Vol. 1767-1839.

Privilegirte Wöchentliche gemeinnützige Nachrichten von und für Hamburg. (From January 2, 1811: Wöchentliche gemeinnützige Nachrichten von und für Hamburg; from June 6, 1813: Affiches, Annonces et Avis divers de Hambourg, oder: Nachrichten, Bekanntmachungen und unterschiedliche Anzeigen von Hamburg; from May 20, 1814: original title) Hamburg: Hermannsche Erben et al. Vol. 1793-1839.

Voght, Caspar. "Acht und zwanzigste Nachricht an Hamburgs wohlthätige Einwohner über den Fortgang der Armenanstalt." In Nachrichten von der Einrichtung und dem Fortgang der Hamburgischen Armen-Anstalt. Vol. 1, 269-272 (Jan 1801). Hamburg: Hoffmann, 1794.

Voght, Caspar, and Johann Arnold Günther. "Zwei Aufsätze über Quellen der Verarmung, im Namen des Hamburgischen Armen-Collegiums entworfen." In Schriften und Verhandlungen der Gesellschaft zur Beförderung der Künste und nützlichen Gewerbe, vol. 1, 390-396. Hamburg: Carl Ernst Blohn, 1792.

\section{Literature}

Aitken, Robbie. "Education and Migration: Cameroonian School Children and Apprentices in the German Metropole, 1884-1914." In Germany and the Black Diaspora: Points of Contact, 1250-1914, edited by Mischa Honeck, Martin Klimke, and Anne Kuhlmann, 213-230. New York, NY, Oxford: Berghahn, 2013.

Becker, Andreas. "Preußens schwarze Untertanen: Afrikanerinnen und Afrikaner zwischen Kleve und Königsberg vom 17. bis ins frühe 19. Jahrhundert." Forschungen zur brandenburgischen und preußischen Geschichte 22, no. 1 (2012): 1-32.

Berlin, Ira. "From Creole to African: Atlantic Creoles and the Origins of African- American Society in Mainland North America." The William and Mary Quarterly 53, no. 2 (1996): 251-288.

Block, Sharon. Colonial Complexions: Race and Bodies in Eighteenth-Century America. Philadelphia, PA: University of Pennsylvania Press, 2018.

Blome, Astrid. "Das Intelligenzwesen in Hamburg und Altona." In Pressewesen der Aufklärung: Periodische Schriften im Alten Reich, edited by Sabine Doering-Manteuffel, Josef Mančal, and Wolfgang Wüst. 183-207. Berlin: Akademie-Verlag, 2001.

Böning, Holger. "Pressewesen und Aufklärung: Intelligenzblätter und Volksaufklärer." In Pressewesen der Aufklärung periodische Schriften im Alten Reich, edited by Sabine DoeringManteuffel, Josef Mančal, and Wolfgang Wüst. 69-119. Berlin: Akademie-Verlag, 2001.

Boulle, Pierre H. "Slave and Other Nonwhite Children in Late-Eighteenth-Century France." In Children in Slavery through the Ages, edited by Gwyn Campbell, Suzanne Miers, and Joseph C. Miller, 169-186. Athens, OH: Ohio University Press, 2009. 
Brahm, Felix, and Eve Rosenhaft, eds. Slavery Hinterland: Transatlantic Slavery and Continental Europe, 1680-1850. Woodbridge, UK, Rochester, NY: The Boydell Press, 2016.

Brana-Shute, Rosemary, and Randy J. Sparks, eds. Paths to Freedom: Manumission in the Atlantic world. Columbia, SC: University of South Carolina Press, 2009.

Costello, Ray. Black Salt: Seafarers of African Descent on British Ships. Liverpool: Liverpool University Press, 2012.

Davis, David Brion. Inhuman Bondage: The Rise and Fall of Slavery in the New World. Oxford, New York, NY: Oxford University Press, 2006.

Degn, Christian. Die Schimmelmanns im atlantischen Dreieckshandel: Gewinn und Gewissen. Neumünster: Wachholtz, 1974.

Domingues da Silva, Daniel B. The Atlantic Slave Trade from West Central Africa. Cambridge, MA: Cambridge University Press, 2017.

Everts, Natalie. "'Brought up Well According to European Standards': Helena van der Burgh and Wilhelmina van Naarssen: Two Christian Women from Elmina." In Merchants, Missionaries and Migrants: 300 Years of Dutch-Ghanaian Relations, edited by Ineke van Kessel, 101-109. Amsterdam: KIT, 2002.

Fatah-Black, Karwan, and Matthias van Rossum. "Slavery in a 'Slave Free Enclave'? Historical Links between the Dutch Republic, Empire and Slavery, 1580s-1860s." WerkstattGeschichte 25, no. 66-67 (2015): 55-73.

Firla, Monika. Exotisch - höfisch - bürgerlich: Afrikaner in Württemberg vom 15. bis 19. Jahrhundert. Stuttgart: Hauptstaatsarchiv, 2001.

Fisher, Michael Herbert. Counterflows to Colonialism: Indian Travellers and Settlers in Britain 1600-1857. Delhi: Permanent Black, 2004.

Frühsorge, Gotthard, Rainer Gruenter, and Beatrix Wolff Metternich, eds. Gesinde im 18. Jahrhundert. Hamburg: Meiner, 1995.

Fryer, Peter. Staying Power: The History of Black People in Britain. London: Pluto Press, 2010.

Gerzina, Gretchen. Black London: Life before Emancipation. New Brunswick, NJ: Rutgers University Press, 1995.

Gilroy, Paul. The Black Atlantic: Modernity and Double Consciousness. Reprinted. London: Verso, 1999.

Gißibl, Bernhard, and Isabella Löhr, eds. Bessere Welten: Kosmopolitismus in den Geschichtswissenschaften. Frankfurt: Campus, 2017.

Glück, Helmut, Mark Häberlein, and Konrad Schröder. Mehrsprachigkeit in der frühen Neuzeit: Die Reichsstädte Augsburg und Nürnberg vom 15. bis ins frühe 19. Jahrhundert. Wiesbaden: Harrassowitz, 2013.

Gøbel, Erik. "Die Schiffahrt Altonas nach Westindien in der zweiten Hälfte des 18. Jahrhunderts.” Jahrbuch // Altonaer Museum in Hamburg 28-31 (1995): 11-24.

Häberlein, Mark. “'Mohren,' ständische Gesellschaft und atlantische Welt: Minderheiten und Kulturkontakte in der frühen Neuzeit." In Atlantic Understandings: Essays on European and American History in Honor of Hermann Wellenreuther, edited by Claudia Schnurmann and Hartmut Lehmann, 77-102. Hamburg: Lit, 2006.

Hannerz, Ulf. “Cosmopolitans and Locals in World Culture." Theory, Culture \& Society 7 (1990): 237-252.

Hauschild-Thiessen, Renate. "Eine 'Mohrentaufe' im Michel 1855." Hamburgische Geschichts- und Heimatblätter 11, no. 1 (1982): 11-12.

Heerten, Lasse. "Ankerpunkte der Verflechtung: Hafenstädte in der neueren Globalgeschichtsschreibung.” Geschichte und Gesellschaft 43, no. 1 (2017): 146-175.

Henke, Klaus-Dirk. “Georg Friedrich Wilhelm Meyer, 1782-1856: Botanik, Ökonomie.” In Göttinger Gelehrte: Die Akademie der Wissenschaften zu Göttingen in Bildnissen und Würdigungen, 
1751-2001, edited by Karl Arndt, Gerhard Gottschalk, and Rudolf Smend, 144. Göttingen: Wallstein, 2001.

Hohendahl, Peter Uwe, ed. Patriotism, Cosmopolitanism, and National Culture: Public Culture in Hamburg 1700-1933. Amsterdam: Rodopi, 2003.

Kaufmann, Miranda. Black Tudors: The Untold Story. London: Oneworld, 2017.

Kopitzsch, Franklin. Grundzüge einer Sozialgeschichte der Aufklärung in Hamburg und Altona. Hamburg: Christians, 1982.

Krampl, Ulrike. "Fremde Sprachen: Adelserziehung und Bildungsmarkt im Frankreich der zweiten Hälfte des 18. Jahrhunderts." In Militär und Mehrsprachigkeit im neuzeitlichen Europa, edited by Helmut Glück and Mark Häberlein, 97-112. Wiesbaden: Harrassowitz, 2014.

Kuhlmann-Smirnov, Anne. Schwarze Europäer im Alten Reich: Handel, Migration, Hof. Göttingen: Vandenhoeck \& Ruprecht, 2013.

Lademann-Priemer, Gabriele, and Ulf Priemer. "Antonio Congo - Ein Afrikaner in Norddeutschland im 19. Jahrhundert: Ein biografischer Versuch.” Accessed February 1, 2018. http://www. glaube-und-irrglaube.de/texte/congo.pdf.

Lind, Vera. "Privileged Dependency on the Edge of the Atlantic World: Africans and Germans in the Eighteenth Century." In Interpreting Colonialism, edited by Byron R. Wells, 369-391. Oxford: Voltaire Foundation, 2004.

Lindemann, Mary. Patriots and Paupers: Hamburg, 1712-1830. New York: Oxford University Press, 1990.

Loose, Hans-Dieter, and Werner Jochmann, eds. Hamburg: Geschichte der Stadt und ihrer Bewohner. Hamburg: Hoffmann und Campe, 1982.

Mallinckrodt, Rebekka von. "Verhandelte (Un-)Freiheit: Sklaverei, Leibeigenschaft und innereuropäischer Wissenstransfer am Ausgang des 18. Jahrhunderts.” Geschichte und Gesellschaft 43 (2017): 347-380.

Mallinckrodt, Rebekka von. "Sklaverei und Recht im Alten Reich," In Das Meer: Maritime Welten in der Frühen Neuzeit, edited by Peter Burschel and Sünne Juterczenka. Cologne: Böhlau, forthcoming.

Manning, Patrick. "Africa and the African Diaspora: New Directions of Study." The Journal of African History 44, no. 3 (2003): 487-506.

Martin, Peter. Schwarze Teufel, edle Mohren. Hamburg: Junius, 1993.

Martone, Eric, ed. Encyclopedia of Blacks in European History and Culture. Westport, CT: Greenwood Publishing Group, 2009.

Michels, Stefanie. "Imperial, atlantisch, europäisch, kosmopolitisch? Globales Bewusstsein in Duala im frühen 19. Jahrhundert." In Bessere Welten: Kosmopolitismus in den Geschichtswissenschaften, edited by Bernhard Gißibl and Isabella Löhr, 281-314. Frankfurt, New York, NY: Campus, 2017.

Mok, Ineke. "Slavernij in de Republiek 3: 'Zwarte negerjongen geabsenteerd.'” Accessed February 15, 2018. https://www.cultuursporen.nl/2017/03/slavernij-in-de-republiek-3-zwartenegerjongen-geabsenteerd/.

Nwankwo, Ifeoma Kiddoe. Black Cosmopolitanism: Racial Consciousness and Transnational Identity in the Nineteenth-Century Americas. Philadelphia, PA: University of Pennsylvania Press, 2005.

Østhus, Hanne. "Slaver og ikke-europeiske tjenestefolk i Danmark Norge på 1700- og begynnelsen av 1800-tallet." Arbeiderhistorie 22, no. 1 (2018): 33-47.

Patterson, Orlando. Slavery and Social Death: A Comparative Study. Cambridge, MA: Harvard University Press, 1982.

Peabody, Sue. Madeleine's Children: Family, Freedom, Secrets, and Lies in France's Indian Ocean Colonies. New York, NY: Oxford University Press, 2017. 
Peabody, Sue, and Keila Grinberg. "Free Soil: The Generation and Circulation of an Atlantic Legal Principle." Slavery \& Abolition 32, no. 3 (2011): 331-339.

Ponte, Mark. "'Al de swarten die hier ter stede comen': Een Afro-Atlantische gemeenschap in zeventiende-eeuws Amsterdam." TSEF/Low Countries Journal of Social and Economic History 15, no. 4 (2019): 33-62.

Ressel, Magnus. "Hamburg und die Niederelbe im atlantischen Sklavenhandel der Frühen Neuzeit." Werkstatt Geschichte, no. 66-67 (2014): 75-96.

Saunders, A.C. de C. M. A Social History of Black Slaves and Freedmen in Portugal, 1441-1555. Cambridge Iberian and Latin American studies. Cambridge: Cambridge University Press, 1982.

Schulte Beerbühl, Margrit. Deutsche Kaufleute in London: Welthandel und Einbürgerung (1600-1818). München: Oldenbourg, 2007.

Sennefelt, Karin. "Runaway Colours: Recognisability and Categorisation in Sweden and Early America, 1750-1820." In Sweden in the Eighteenth-Century World: Provincial Cosmopolitans, edited by Göran Rydén, 225-46. Farnham: Ashgate, 2013.

Sow, Noah. Deutschland Schwarz Weiß: Der alltägliche Rassismus. 6th ed. München: Goldmann, 2009.

Steinbruch, Karl-Heinz. "Ein schöner Mohr und treuer Diener: Auch an Mecklenburgs Höfen wurden Afrikaner getauft und in Dienst genommen." Mecklenburg-Magazin: Regionalbeilage der Schweriner Volkszeitung und der Norddeutschen Neuesten Nachrichten, no. 13 (2002): 26.

Sulzbacher, Christine. "Beten - dienen - unterhalten: Zur Funktionalisierung von Afrikanern und Afrikanerinnen im 19. Jahrhundert in Österreich." In Von Soliman zu Omofuma: Afrikanische Diaspora in Österreich 17. bis 20. Jahrhundert, edited by Walter Sauer, 99-128. Innsbruck: Studienverlag, 2007.

Sweet, James H. "The Iberian Roots of American Racist Thought." The William and Mary Quarterly 54, no. 1 (1997): 143-166.

Tantner, Anton. "Adressbüros im Europa der Frühen Neuzeit." Habilitation thesis, Faculty of Historical and Cultural Studies, University of Vienna, 2011. Accessed January 28, 2019. https://uscholar.univie.ac.at/get/o:128115.

Tantner, Anton. Die ersten Suchmaschinen: Adressbüros, Fragämter, Intelligenz-Comptoirs. Berlin: Klaus Wagenbach, 2015.

Vertovec, Steven, and Robin Cohen, eds. Conceiving Cosmopolitanism: Theory, Context, and Practice. New York, NY: Oxford University Press, 2002.

Vogt, Annette Christine. Ein Hamburger Beitrag zur Entwicklung des Welthandels im 19. Jahrhundert: Die Kaufmannsreederei Wappäus im internationalen Handel Venezuelas und der dänischen sowie niederländischen Antillen. Stuttgart: Steiner, 2003.

Vrij, Jean Jacques. "Susanna Dumion en twee van haar lotgenoten: Drie Afro-Westindische vrouwen in achttiende-eeuws Amsterdam." Wi Rutu, Tijdschrift voor Surinaamse Genealogie 15, no. 1 (2015): 18-31.

Weber, Klaus. Deutsche Kaufleute im Atlantikhandel 1680-1830: Unternehmen und Familien in Hamburg, Cádiz und Bordeaux. München: Beck, 2004.

Werbner, Pnina. "Vernacular Cosmopolitanism." Theory, Culture \& Society 23, no. 2-3 (2016): 496-498.

Zack, Naomi. Philosophy of Science and Race. New York, NY: Routledge, 2002. 


\section{Invisible Products of Slavery: American Medicinals and Dyestuffs in the Holy Roman Empire}

When thinking about the early modern American plantation complex, an image of African slaves working sugar mills or harvesting cotton balls, coffee or cocoa beans, or tobacco leaves comes to mind for most people. ${ }^{1}$ Far less likely are associations with slaves cultivating ginger, planting indigo seedlings, scraping pulp from the cassia fistula husks, or grating annatto. ${ }^{2}$ It may surprise some readers to learn that African slaves not only did such work on American plantations but that the medicinals and dyestuffs their labor produced were sought-after products that were cultivated in large quantities and sold for considerable profit in Europe. The following contribution uses the Holy Roman Empire as a case study to tackle the question why certain products have been less thoroughly researched than others. In pursuing this issue, I will also show that Central Europe was well-integrated into the Atlantic and global economy both on the economic and on the discursive level. ${ }^{3}$ The same American plantation products that were shipped to French, English, or Portuguese

1 The amount of literature on the better-known "plantation products" is vast. See e.g. Annerose Menninger, Genuss im kulturellen Wandel: Tabak, Kaffee, Tee und Schokolade in Europa (16.-19. Jahrhundert) (Stuttgart: Franz Steiner, 2004); Stuart Schwartz, Tropical Babylons: Sugar and the Making of the Atlantic World, 1450-1680 (Chapel Hill: University of North Carolina Press, 2004); Russell R. Menard, Sweet Negations: Sugar, Slavery, and Plantation Agriculture in Early Barbados (Charlottesville: University of Virginia Press, 2006); Nikia Harwich-Vallenilla, Histoire du chocolat (Paris: Ed. Desjonquères, 1992); Sven Beckert, Empire of Cotton: A Global History (New York: Knopf, 2014); Marcy Norton, Sacred Gifts, Profane Pleasures: A History of Tobacco and Chocolate in the Atlantic World (Ithaca: Cornell University Press, 2008).

2 See e.g. Jutta Wimmler, The Sun King's Atlantic: Drugs, Demons and Dyestuffs in the Atlantic World, 1640-1730 (Leiden/Boston: Brill, 2017).

3 See e.g. Susanne Lachenicht, ed., Europeans Engaging the Atlantic: Knowledge and Trade, 1500-1800 (Frankfurt: Campus, 2014); Felix Brahm and Eve Rosenhaft, eds., Slavery Hinterland: Transatlantic Slavery and Continental Europe, 1680-1850 (Woodbridge: Boydell \& Brewer, 2016); Kim Siebenhüner, John Jordan, and Gabi Schopf, eds., Cotton in Context: Manufacturing, Marketing, and Consuming Textiles in the German-Speaking World (1500-1900) (Cologne: Böhlau, 2019); Jutta Wimmler and Klaus Weber, eds., Globalized Peripheries: Central Europe and the Atlantic World, 1680-1860 (Woodbridge: Boydell \& Brewer, 2020).

Notes: Research for this article was funded by the German Research Foundation (WE 3613/2-1, "The Globalized Periphery. Atlantic Commerce, Socioeconomic and Cultural Change in Central Europe, 1680-1850"). 